\title{
PENYEBARAN DAN TINGKAT SERANGAN KUTU PUTIH PEPAYA DI SULAWESI UTARA
}

\author{
SPREADING AND INTENSITY OF ATTACK OF PAPAYA MEALYBUG AT NORTH \\ SULAWESI
}

\author{
Nasution Suharto Anes'), Max Tulung') dan Juliet M. Eva Mamahit'2) \\ 1)Balai Perlindungan Tanaman Pangan dan Hortikultura Sulawesi Utara \\ 2)Fakultas Pertanian Universitas Sam Ratulangi Manado
}

\begin{abstract}
Papaya mealybug, Paracoccus marginatus (Hemiptera: Pseudococcidae) in Indonesia was reported attacking papaya in 2008 in Bogor. In North Sulawesi reported attacked papaya in 2009 in Manado. The purpose of research to determine the level of attacks and spreading of papaya mealybug $P$. marginatus in North Sulawesi. The study was conducted from December 2010 - September 2011. Dissemination papaya mealybug based on altitude in North Sulawesi, namely: Bitung, North Minahasa, Minahasa, South Minahasa, South Minahasa, Tomohon, and Manado. Papaya plants were attacked by the intensity of the attacks seen low $<25 \%$, moderate $25-50 \%$ and $50-90 \%$ by high. Samples of papaya mealybug brought in the Laboratory Pest and Entomology, Faculty of Agriculture Unsrat Manado to be identified. Results showed papaya mealybug pest infestation has spread over several papaya plantation in North Sulawesi. Papaya mealybug attack papaya covering several areas in the lowlands (<200 $\mathrm{m}$ asl) to high area $(800 \mathrm{~m}$ asl). Spreading pf papaya mealybug attack papaya plantation of Minahasa, Manado, Bitung, Tomohon, North Minahasa and South East Minahasa. Attack rates range of mealbug from low, moderate, and high.
\end{abstract}

Keyword : Spreading, intensity attack, Paracoccus marginatus

ABSTRAK

Kutu putih pepaya Paracoccus marginatus (Hemiptera: Pseudococcidae) di Indonesia dilaporkan menyerang pepaya tahun 2008 di Bogor. Di Sulawesi Utara dilaporkan menyerang pepaya tahun 2009 di Manado. Tujuan penelitian untuk mengetahui penyebaran dan tingkat serangan kutu putih pepaya $P$. marginatus di Sulawesi Utara. Penelitian dilakukan mulai Desember 2010 - September 2011. Data penyebaran kutu putih pepaya didasarkan pada ketinggian tempat di Sulawesi Utara, yaitu : Bitung, Minahasa Utara, Minahasa, Minahasa Tenggara, Minahasa Selatan, Tomohon, dan Manado. Tanaman pepaya yang terserang dilihat intensitas serangan yaitu serangan ringan $<25 \%$, sedang $25-50 \%$ dan berat 50-90\%. Sampel tanaman yang terserang kutu putih pepaya dan musuh alami dibawa di laboratorium Hama dan Entomologi, Fakultas Pertanian Unsrat Manado untuk diidentifikasi. Hasil penelitian menunjukkan hama kutu putih pepaya telah tersebar di beberapa perkebunan pepaya di Sulawesi Utara. Serangan kutu putih pepaya meliputi beberapa daerah di dataran rendah (<200 m dpl) sampai di daerah tinggi (800 $\mathrm{m}$ dpl).

Kata Kunci : Penyebaran, intensitas serangan, Paracoccus marginatus

Eugenia Volume 18 No. 1 April 2012 


\section{PENDAHULUAN}

Negara Indonesia yang terletak digaris khatulistiwa memiliki beragam potensi sumber daya alam untuk dimanfaatkan bagi kemakmuran rakyat. Salah satu potensi kekayaan alam yang dimiliki negara Indonesia ialah keanekaragaman jenis tanaman yang mempunyai nilai ekonomis. Sebagai negara tropis, Indonesia memiliki aneka buah lokal unggul yang tumbuh mulai dataran rendah sampai tinggi.

Komoditi hortikultura mencakup berbagai jenis tanaman seperti buah-buahan, sayur-sayuran, tanaman hias, dan tanaman biofarmaka. Komoditi tersebut mempunyai peluang pasar baik di dalam negeri maupun di luar negeri dalam pelaksanaan pasar global. Hal ini disebabkan karena komoditi tersebut mempunyai nilai ekonomi yang tinggi. Pertambahan jumlah penduduk yang diikuti dengan meningkatnya keadaan ekonomi dan kesadaran masyarakat akan pentingnya asupan gizi berdampak terhadap peningkatan permintaan pangan khususnya akan komoditi hortikultura baik kwantitas maupun kwalitas (Anonim, 2002).

Bagian lain ialah tuntutan masyarakat akan kebutuhan produk hortikultura yang bermutu semakin lama semakin meningkat. Meningkatnya pendapatan dan kesejahteraan masyarakat Indonesia, yang dicirikan dengan berkembangnya pasar swalayan di kota besar maupun kota kecil di tanah air, hal ini memberikan peluang dan tantangan tersendiri karena pasar tesebut melayani pangsa pasar masyarakat menengah keatas (Dimyati, 2008).

Tanaman Pepaya (Carica papaya L.) merupakan salah satu komoditi dari keanekaragaman jenis tanaman buah-buahan yang memiliki nilai ekonomis untuk menambah devisa negara. Secara statistik, produksi buah tropika Indonesia terus mengalami dinamika dari tahun ke tahun. Tahun 2007 produksi buah mencapai 17.116.662 ton. Tahun 2008 meningkat sekitar 4,18\% menjadi 17.831.252 ton. Tahun 2009 mengalami penurunan $0.57 \%$ dari produksi tahun 2008 menjadi 17.727.926 ton buah segar. Jumlah produksi buah nasional yang cukup besar, ternyata kontribusi ekspor Indonesia masih rendah. Tahun 2005, kontribusi Indonesia baru 0,15\% dari total ekspor dunia.

Berdasarkan data FAO 2007, sedikitnya 12,4 juta ton pisang diperdagangkan, kemudian nenas 1,6 juta ton, mangga 732 ribu ton dan pepaya 208 ribu ton. Amerika Serikat dan negaranegara Eropa tercatat sebagai negara terbesar pengimpor buah tropika, disusul negara Timur Tengah dan Asia Timur. Tahun 2006, volume ekspor buah Indonesia mencapai 26.236 ton atau senilai US \$ 144.492.469. Tahun 2007, ekspor buah mengalami penurunan sekitar $39,92 \%$. Tahun 2008 volume ekspor buah meningkat sebesar $105,50 \%$ menjadi 32.389 ton dengan nilai US \$ 234.867.444. Tahun 2009 menjadi 418.764 ton dengan nilai 331,198 juta US \$. Data ekspor buah pepaya tahun 2004, 50 ton tahun 2005, 60 ton tahun 2006, 70 ton tahun 2007, 80 ton tahun 2008 sampai tahun 2010 masing-masing 100 ton (Anonim, 2010).

Tanaman pepaya dijumpai hampir di seluruh provinsi di Indonesia, karena memiliki kesesuaian iklim yang baik untuk pertumbuhannya. Komoditi hortikultra ini khususnya di Provinsi Sulawesi Utara banyak dijumpai pertanamannya yang tumbuh mulai di dataran rendah sampai pada dataran tinggi. Petani melakukan budidaya tanaman pepaya untuk pemenuhan kebutuhan gizi masyarakat maupun diantar pulaukan ke luar daerah Provinsi Sulawesi Utara.

Sebagai upaya untuk meningkatkan produksi pepaya di Indonesia, pemerintah diperhadapkan dengan berbagai permasalahaan, seperti terbatasnya areal pertanaman, rendahnya penguasaan teknologi budidaya tanaman pepaya oleh petani/masyarakat, teknologi yang kurang memadai serta adanya gangguan secara fisik (lingkungan makro dan mikro) maupun biotik (jasad renik/penyakit, gulma dan serangga) (Cahyono, 1995). Khusus Organisme Pengganggu Tumbuhan (OPT) pada tanaman pepaya, sekarang ini OPT yang perlu diwaspadai petani adalah hama kutu putih pepaya Paracoccus marginatus.

Kutu putih pepaya $P$. marginatus di Indonesia pertama-tama ditemukan pada tanaman pepaya di Bogor pada bulan Mei 2008 oleh Tim IPM CRSP/Virginia Tech/Clemson University, USA. 
Di Provinsi Sulawesi Utara ditemukan pada tanaman pepaya di Kelurahan Batukota Kota Manado pada bulan Agustus 2009 (Sembel, 2009).

Penyebaran kutu putih pepaya sudah dilaporkan menyerang tanaman pepaya yang dapat disebarkan oleh angin, terbawa benih/bibit, orang, serangga lain dan burung (Mamahit dan Sembel 2011). Keberadaan kutu putih pepaya yang cukup tinggi dan bersifat polifag mempunyai potensi menyebar yang sangat cepat (Walker, et al., 2003).

Hama kutu putih pepaya $P$. marginatus bukan hanya menjadi masalah nasional di Indonesia, tetapi menjadi masalah internasional, karena hama ini menyebar dengan sangat cepat keseluruh dunia terutama di daerah beriklim tropis dan sub tropis. Kondisi ini mendukung perkembangan dan penyebaran. Hama kutu putih pepaya mengancam tanaman pepaya dan jenisjenis tanaman lainnya karena bersifat polifag atau pemakan banyak jenis tanaman pertanian maupun tanaman hortikultura dan ornamental.

Hama kutu putih pepaya, selain menyerang tanaman pepaya, juga dapat menyerang tanaman ubi kayu, jarak, dan tanaman lain yang mengeluarkan getah (Sembel dan Moniaga, 2009). Hama kutu puth pepaya dapat menyerang bagian tanaman seperti buah, daun, tangkai daun, dan bunga pepaya. Hama kutu putih pepaya menyerang tanaman pepaya baik yang masih muda dan yang sudah berbuah serta dapat mematikan tanaman pepaya umur kurang dari tiga bulan sejak awal infestasi hama pada tanaman. Serangan hama kutu putih pepaya menjadi ancaman besar bagi petani pepaya di Indonesia dan khususnya di Provinsi Sulawesi Utara.

Hama kutu putih pepaya masih relatif baru di Provinsi Sulawesi Utara, sehingga berbagai karakter biologis dan lingkungan yang mempengaruhinya masih banyak yang perlu dipelajari/dikaji lebih mendalam diantaranya tentang penyebaran, tingkat serangan dan musuh alami. Berdasarkan hal tersebut diatas, maka perlu dipelajari penyebaran, tingkat serangan hama kutu putih pepaya pada lahan pertanaman pepaya berdasarkan ketinggian tempat di daerah Minahasa, Manado, dan Bitung Provinsi Sulawesi Utara.
Penelitian ini bertujuan untuk : 1) Mengetahui penyebaran Kutu putih pepaya $P$. marginatus di Minahasa, Manado, dan Bitung. 2) Mengetahui tingkat serangan kutu putih pepaya $P$. marginatus di Minahasa, Manado, dan Bitung.

Penelitian penyebaran kutu putih pepaya $P$. marginatus dan tingkat serangannya dapat menjadi informasi untuk pengendalian hama kutu putih pepaya $P$. marginatus di Minahasa, Manado dan Bitung di Provinsi Sulawesi Utara.

\section{METODE PENELITIAN}

Penelitian lapangan dilaksanakan pada beberapa wilayah/lokasi tanaman pepaya berdasarkan ketinggian tempat di Minahasa, Manado dan Bitung Provinsi Sulawesi Utara yaitu : ( 0-200 m dpl, 200-400 m dpl, 400-600 m dpl dan 600-800 m dpl) dan di Laboratorium Hama /Entomologi Fakultas Pertanian, Universitas Sam Ratulangi Manado. Waktu penelitian dilaksanakan selama sembilan bulan sejak bulan Desember 2010 sampai September 2011.

Penelitian penyebaran dan tingkat serangan kutu putih pepaya $P$. marginatus menggunakan metode survey pada perkebunan pepaya dan dilaksanakan berdasarkan ketinggian tempat ( $m$ dpl) dengan melihat sebaran secara geografis yang dilakukan dengan alat GPS pada ketinggian tempat masing-masing yaitu : ketinggian 0-200 m dpl, 200-400 m dpl, 400-600 m dpl dan 600-800 m $\mathrm{dpl}$, setiap lokasi diambil sampel dan diadakan pengamatan pada tanaman pepaya untuk melihat apakah terserang hama kutu putih pepaya atau tidak terserang/sehat. Parameter pengamatan yaitu: ada tidaknya gejala serangan hama kutu putih pepaya, tingkat serangan, varietas pepaya dan kondisi pertanaman. Sebelum identifikasi kutu putih pepaya akan dilaksanakan, mula-mula nimfa maupun imago dikumpulkan dari beberapa areal pertanaman pepaya. Daun dan buah yang terdapat kutu putih pepaya diambil/dipotong dan dimasukkan kedalam kantong plastik. Sampel dibawa ke laboratorium untuk diamati dan diidentifikasi.

Identifikasi serangga yang dilakukan seperti mengambil gambar merupakan salah satu cara untuk mendapatkan deskripsi dalam 
identifikasi suatu serangga. Hal ini akan menampilkan rincian penting seperti berapa banyak tungkai, warnanya, pola, bentuk tubuh secara keseluruhan, dan jumlah oceli, ruas antena atau rambut di tungkai, bahkan dapat mencatat semua fitur seperti sebagai bantalan melingkar di ujung tungkai dan pori-pori pada tibia. Identifikasi diperlukan untuk memastikan spesies kutu putih pepaya yang ada pada pertanaman pepaya. Identifikasi serangga menggunakan kunci determinasi dari Williams and de Willink (1992).

\section{HASIL DAN PEMBAHASAN}

\section{Penyebaran Kutu Putih Pepaya P. marginatus}

Hasil penelitian menunjukkan ditemukan bahwa hama kutu putih pepaya telah menyebar pada semua ketinggian tempat. Penyebaran kutu putih di Provinsi Sulawesi Utara sudah mencakup wilayah Minahasa, Manado dan Bitung. Pada ketinggian 0-200 m dpl ditemukan bahwa serangan kutu putih pepaya lebih banyak wilayah serangannya meliputi 35 tempat/desa/kelurahan. Ketinggian 200-400 m dpl ditemukan sebanyak empat tempat/ desa/kelurahan, pada ketinggian 400-600 m dpl kutu putih pepaya ditemukan pada sepuluh tempat/ desa/kelurahan dan pada ketinggian 600-800 m dpl ditemukan pada empat tempat/desa/kelurahan. Hasil penelitian menunjukkan bahwa kutu putih pepaya lebih menyukai hidup pada ketinggian di bawah $200 \mathrm{~m}$ dpl. Hal ini disebabkan pada ketinggian di bawah $200 \mathrm{~m}$ dpl suhu udara lebih tinggi hal ini sesuai untuk pertumbuhan dan perkembangan kutu putih pepaya.

\section{Tingkat Serangan Kutu Putih Pepaya $\boldsymbol{P}$. marginatus}

Tingkat serangan kutu putih pepaya ditemukan bervariasi dari serangan ringan, serangan sedang, sampai serangan berat. Pada umumnya tingkat serangan kutu putih pepaya yang ditemukan ialah serangan berat. Hal ini ditemukan di lokasi Girian Weru, Manembo-nembo Bawah, Girian Bawah, Tambala, Pondang, Kawangkoan Bawah, Uwuran Dua, Pinokalan, Girian Indah, Danowudu dan lain-lain. Tingkat serangan berat terlihat dari serangan kutu puth pepaya sudah terdapat pada keseluruhan tanaman mulai daun, batang, cabang sampai buah. Buah yang terserang ditutupi oleh kumpulan kutu putih pepaya dan buah mudah gugur dan kadang ditumbuhi oleh jamur embun jelaga.

Terjadinya perbedaan tingkat serangan kutu putih pepaya disebabkan pada lokasi dengan tingkat serangan berat pada saat penelitian berada pada musim kemarau. Faktor lingkungan memberikan keuntungan untuk pertumbuhan dan perkembangan dari kutu putih pepaya $P$. marginatus. Faktor lainnya yang mendukung ialah faktor dalam yaitu potensi biologi dari serangga kutu putih pepaya $P$. marginatus, dimana serangga ini memiliki ukuran tubuh yang kecil serta kepiridian tinggi dan kemampuan berkembang biak yang cepat karena sifat dari serangga ini yang mampu bereproduksi tanpa terjadinya fertilisasi (perbanyakan secara partenogenesis). Musim kemarau telur-telur betina hasil pembiakan secara partenogenesis akan menghasilkan individu jenis jantan maupun betina, yang selanjutnya menghasilkan telur-telur yang dibuahi lebih banyak.

Curah hujan dan angin juga berpengaruh pada kehidupan kutu putih pepaya $P$. marginatus sebab dengan ukuran tubuh yang kecil serangga hama kutu putih pepaya bisa terjatuh, terbawa angin sehingga penyebaran dari serangga kutu putih pepaya cepat. Hal ini terbukti untuk semua daerah sudah terdapat serangan hama kutu putih pepaya.

Makanan sangat berpengaruh pada perkembangan serangga hama kutu putih pepaya $P$. marginatus, karena tanaman pepaya dapat tumbuh dimana-mana. Dengan tersedianya tanaman pepaya maka sumber makanan juga tersedia. Hal ini berpengaruh pada perkembangan kutu putih pepaya.

\section{KESIMPULAN DAN SARAN}

\section{Kesimpulan}

Penyebaran kutu putih pepaya $P$. marginatus di Minahasa, Manado dan Bitung Provinsi Sulawesi Utara ditemukan mulai dari daerah dataran rendah sampai daerah dataran tinggi (0-800 m dpl). Ketersediaan makanan (inang) 
yaitu tanaman pepaya dapat tumbuh mulai dataran rendah sampai dataran tinggi, faktor luar (eksternal factor) juga mempengaruhi perkembangan dari kutu putih pepaya seperti suhu, angin dan lain lain, serta faktor dalam (internal factor) seperti kemampuan serangga untuk menghasilkan keturunan.

Tingkat serangan kutu putih pepaya $P$. marginatus pada lokasi pertanaman pepaya bervariasi mulai dari serangan ringan, sedang dan berat.

\section{Saran}

Perlu dilakukan penelitian lebih lanjut tentang penyebaran dan intensitas serangan kutu putih pepaya $P$. marginatus di Daerah Bolaang Mongondow, Kepulauan Sangihe dan Talaud Provinsi Sulawesi Utara.

\section{DAFTAR PUSTAKA}

Anonim. 1995. Cara Koleksi Serangga. Program Nasional Pengendalian Hama Terpadu. Direktorat Perlindungan Tanaman. Jakarta.

2002a Binomial authority William \& Granara de Willink, 1992 wpedia.goo.ne.jp/enwiki/Paracoccus marginatus. Diakses 6 Januari 2011. 2002b. Buku Teknologi Pengendalian Hama Terpadu, Dirjen Bina Produksi Tanaman Pangan. Direktorat Perlindungan Tanaman. Jakarta.

2010. Pengamatan OPT Hortikultura. Direktorat Jenderal Hortikultura Direktorat Perlindungan Tanaman Hortikultura. Jakarta.

Benson. 2010. Annual Report. IPMCRSP Project. Sam Ratulangi University, Manado. Indonesia.

Cahyono, B. 1995. Budidaya Hortikultura dan Analisa Usaha Tani, Kanisius, Yogyakarta.

DeBach, P. 1964. Succes, trends and future possibities. In biological control of insect pest and weeds. Ed. By P. Debach. Reinhold Pub.

Dimyati, A. 2008 Membangun Hortikultura Berdasarkan Enam Pilar Pengembangan.
Direktorat Jenderal Hortikultura, Departemen Pertanian. Jakarta.

Heu, R.A. dan M.T. Fukuda. 2004. Papaya mealybug, Paracoccus marginatus Williams and Granara de Willink (Homoptera: Pseudococcidae). State of Hawaii Department of Agriculture, New Pest Advisory No. 04-03.

Jumar. 1997. Entomologi Pertanian. Penerbit Rineka Cipta. Jakarta.

Kalie, M. B. 1990. Bertanam Pepaya. Penebar Swadaya, Jakarta.

Kunimoto, S.L. 2006. Papaya mealybug. Department of Agriuculture. Stae of Hawaii. Biological Control Section Project.

Lidya, M.I. 2008. Survei Serangan Hama Baru Paracoccus marginatus (Homoptera: Pseudococcidae) pada Pertanaman Pepaya di Kabupaten Bogor.

Mamahit, J.M.E. dan D.T. Sembel. 2011. Penyebaran dan Musuh Alami Hama Kutu Putih Paracoccus marginatus William and Granara de Willink (Hemiptera : Pseudococcidae) pada Tanaman Pepaya di Sulawesi Utara. Laporan Hasil Penelitian Fakultas Pertanian Unsrat.

Meyerdirk, D.E. and W.C. Kauffman. 2001. Status on the Development of a biological control program for Paracoccus merdiatus William, papaya mealybug. Paper presented at IV International Scientific Seminar of Plant Health. Veradera, Cuba, June 10-15, 2001 (abstract).

Meyerdirk, D.E., R. Muniappan, J. Bomba, and G.V.P. Reddy. 2004. Biological Control Of The papaya mealybug, Paracoccus marginatus (Hemiptera:Pseudococcidae) In Guam. Plant Protection Quaterly 19:110-114

Miller D. R. and G. L. Miller. 2002. Redescription of Paracoccus marginatus Williams and Granara de Willink (Hemiptera : Coccidae; Pseudococcidae) Includeing Descriptions of the Immature Stage and Adult Male. Proc. Entomol. Soc. Wash 104 : 1-23.

Muniappan, R., D.E. Meyerdirk, F.M. Sengebau, D.N. Berriger, and G.V.P. Reddy. 2006. 
Classical Biological Control of the papaya mealybug, Paracoccus marginatus (Hemiptera:Pseudococcidae) in the Republic of Palau. Florida Entomologist: 89(2): 21-217.

Natawigena. 1990. Faktor-faktor yang Mempengaruhi Kehidupan Serangga. Penerbit Armico Bandung.

Oka. I.N. 1998. Pengendalian Hama Terpadu dan Implementasinya Indonesia. Yogjakarta.

Price, P.W. 1984. Insect Ecologi. John Wiley and Sons. New York. Toronto. Singapura. Pepaya terkena serangan hama kutu putih, http://4.bp.blogspot.com).

Rebu, Y.U., I.W. Winasa, A. Rauf, 2010. Potensi Parasitoid Acerophagus Papaya untuk Pengendalian Hayati. Seminar Dalam Rangka HUT ke 40 Perhimpunan Entomologi Indonesia. Jogya, 1-2 Oktober 2010.

Sartiami, D. Dadang, R. Anwar, I.S. Harahap. 2009. Persebaran Hama Baru Paracoccus marginatus di Provinsi Jawa Barat, Banten dan DKI Jakarta. Prosiding Seminar Nasional Perlindungan Tanaman, Bogor 56 Agustus 2009.

Sembel, D.T. 2009. Hama Baru Tanaman Pepaya, Paracoccus marginatus: Suatu Ancaman bagi Petani Pepaya di Sulawesi Utara. Media Komentar Manado. Oktober 2009.
Sembel, D.T. dan W. Moniaga. 2009. Survey Hama Baru, Paracoccus marginatus Williams And Granara De Willink (Homoptera: Pseudococcidae) pada Tanaman Pepaya Di Sulawesi Utara. Eugenia 15(2):108-114.

Stehr, F.W. 1975. Parasitoid and Predators in pest management. Introduction to Insect Pest Management. Dalam Oka, I.N. 1995. Pengendalian Hama Terpadu dan Implementasinya di Indonesia. Gajah Mada University Press. Yogyakarta.

Subyanto. 1991. Kunci Determinasi Serangga. Program Nasional PHT. Kanisius

Sunjaya, P.I. 1970. Dasar-dasar Ekologi Serangga. Bagian Ilmu Hama Tanaman Pertanian, Fakultas Pertanian IPB, Bogor.

Untung, K. 1993. Pengantar Pengelolaan Hama Terpadu. Yogjakarta.

Walker A., M. Hoy and D. Meyerdick. 2003. Papaya Mealybug. University of Florida Institute of Food (2011) and Agricultural Sciences.

Williams D.J., and M.C.G. de Willink. 1992. Mealybugs of Central and South America. Wallingford Oxon : CAB International.

William D.J. 2004. Mealybug of Southern Asia. Kuala Lumpur. Malaysia : Southdene SDN BHD. 
